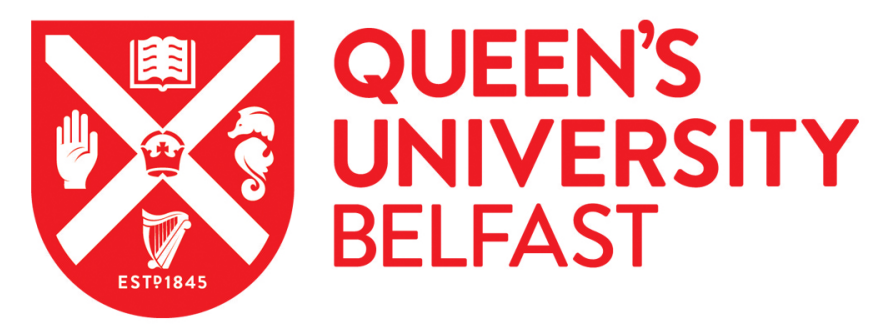

\title{
The Teenage Gaze: Teens and Tourism in Belfast
}

Leonard, M. (2019). The Teenage Gaze: Teens and Tourism in Belfast. Childhood. https://doi.org/10.1177/0907568219843326

\section{Published in: \\ Childhood}

\section{Document Version:}

Peer reviewed version

Queen's University Belfast - Research Portal:

Link to publication record in Queen's University Belfast Research Portal

\section{Publisher rights}

(c) 2019 The Authors. This work is made available online in accordance with the publisher's policies. Please refer to any applicable terms of use of the publisher.

\section{General rights}

Copyright for the publications made accessible via the Queen's University Belfast Research Portal is retained by the author(s) and / or other copyright owners and it is a condition of accessing these publications that users recognise and abide by the legal requirements associated with these rights.

Take down policy

The Research Portal is Queen's institutional repository that provides access to Queen's research output. Every effort has been made to ensure that content in the Research Portal does not infringe any person's rights, or applicable UK laws. If you discover content in the Research Portal that you believe breaches copyright or violates any law, please contact openaccess@qub.ac.uk. 


\title{
The Teenage Gaze: Teens and Tourism in Belfast
}

\begin{abstract}
This article addresses the absence of children in tourism studies by outlining an innovative case study involving teenagers co-constructing a bus tour of Belfast. Seventeen young people, aged 16 took part in designing a tour of Belfast that was subsequently facilitated by a major tour company operating in the city. The article outlines how young people's local spatial knowledge challenges mainstream adult discourses and remains an untapped resource with the potential to contribute significantly to tourism's understandings of divided cities providing existing tourism frameworks are extended to incorporate young people's own ways of seeing and experiencing their everyday spatial lives.
\end{abstract}

\section{Introduction: Where are the Children in Tourism Studies?}

Childhood studies is increasingly seen as a multi/inter-disciplinary subject drawing on and contributing to debates in sociology, anthropology, psychology, geography and other ever growing disciplines. However, the contribution of childhood studies to tourism studies remains underdeveloped with children marred by their absence rather than their presence. Peoria and Timothy (2014) in a review of abstracts for the 'Annals of Tourism Research' found that only eight studies included children in their abstracts. While Skelton and Gough (2013) in a review of articles published in 'Urban Studies' found that only $1 \%$ focused on young people. In a similar vein, Kerr and Price (2016) looked at visits to 'dark tourism' sites, defined as sites of conflict, death and suffering, and a systematic review of peer-reviewed literature on the topic revealed that out of 72 identified papers, only 5 included references to how such sites view young people. Their later work (Kerr and Price, 2018) examined a range of research which suggested that children are regarded as reacting inappropriately at such sites including playing war games at battlefield sites, playing music at concentration camps and climbing on war 
memorials. Yet they argue that their analysis adds weight to the view that children and adults see the same sites through different eyes and that more child-centred methods are needed to capture and understand their views rather than seeing their behaviour through an adult lens (Price and Kerr, 2018).

Where children are included in tourism research, it is often in a passive way as members of families going on holidays with Uri (2002) arguing that most adult holidays stem from a nostalgia for childhood based on partial and idealised images of holidays remembered from one's childhood. Uri (2002) argues that the tourist gaze needs to be factored into any analysis of tourism and he outlines how the tourist (adult) gaze connects tourists with the sights they visit. Led and influenced by adult tour guides, adult tourists gaze on visited places and inject landscapes with tour guides' transmitted meanings. Uri's seminal work on the tourist gaze has dominated tourist studies but has provoked strong criticism from a number of authors who suggest that tourists are rendered passive in his analysis (Mao, 2006). Uri (2002) acknowledges that there is no universal tourist gaze but his work and that of most of his critics do not move beyond an adult gaze, hence generation is rendered invisible. Even those critics who bring in the agency of adults as tourists, for the most part, do not extend this agency to children and young people. Hence, while challenges to the passivity of adults as tour consumers are relevant and justified, there remains a need to incorporate the voices of young people who are often absent in tourism research and in the process relocate them as active agents of their everyday lives.

Young people are particularly absent in city based research despite the fact that more than half the world's children live in cities (Skelton and Gough, 2013). Attempts to rectify this gap has been undertaking by a number of children's geographers whose work on the microgeographies of young people emphasises that examining the place use and spatial behaviour of young people can contribute significantly to understandings of space and place (Smith and 
Mills, 2019). Young people occupy and negotiate cities. They actively move through cities and localities yet often remain invisible and viewed as out of place (Sibley, 1995). Repositioning children as social actors challenges their invisibility and encourages reflection on how they create urban spaces. Politics is interweaved with how public space is encountered and used. Hence, understanding children's everyday spatial practices sheds light on how they construct and perform their political identities (Celle, 2013). Positioning young people as knowledgeable holders of spatial information and considering them as active participants in city life with the ability to provide competent input into how cities are experienced and negotiated, sheds light on the messiness and complexity of city life.

As existing users of city space, young people's perspectives should be a necessary aspect of understanding how cities are perceived and encountered. Hence, there is a pressing need for not just including children in tourism research but developing theoretical and empirical frameworks which bring their experiences in the here and now to the fore. Using frameworks and constructs developed within childhood studies has enabled teen specific geographies to emerge that illustrate how young people often have different 'ways of seeing' from adults and their insights bring new perspectives into understanding the accomplishment of everyday spatial practices. As yet, tourism studies have been slow to apply these perspectives and for the most part, the voices of young people remain silent in tourism research. This paper aims to address this lacuna by drawing on a case study which illustrates how teenagers are an untapped resource with the potential to contribute significantly to tourism's understandings of space and place providing existing tourism frameworks are extended to incorporate young people's own terms of reference. The case study involves young people deciding on a tour route and interacting with an adult tour guide to co-construct the discourse presented. The research suggests that children as members of host communities can contribute positively to tourism research. Children's ways of seeing their localities, communities, cities and nations 
could effectively contribute to expanding understandings of space and place. While the recent merging of children's studies with children's geographies have moved children's placed-based perspectives on to the research agenda, tourism studies continues to marginalise and silence children's perspectives. This case study highlights the distinctive contribution children can bring to understanding divided cities by illuminating the role they could play in tourism.

\section{Belfast: A contested city}

Before turning to the case study, it is necessary to briefly outline the impact of the conflict, colloquially referred to as 'the troubles' which since 1969 claimed over 3,700 lives (Margie and Dickson, 2003). While the city had a history of residential segregation into largely nationalist Catholic communities and largely unionist Protestant communities, the conflict escalated the spread and development of segregated communities. Since the signing of the Belfast/Good Friday Agreement in 1998, the city has experienced a significant reduction in conflict related deaths and incidents but Nolan (2014) argues that, for the most part, there is peace without reconciliation. The 'marching season' whereby one group celebrates its identity through parading through the city, at times, is accompanied by social unrest and sectarianism remains an ongoing legacy of 'the troubles' sustaining high levels of residential segregation (McAlister et al. 2014). Many Catholics and Protestants continue to live in adjacent segregated communities often characterised by poverty and deprivation where the benefits of the peace process have been limited. The reimaging of Belfast as a 'post-conflict' city tends to gloss over these enduring divisions.

\section{Background to the Case Study}

The case study emerged out of a wider project concerned with examining the extent to which teenagers from segregated localities in Belfast viewed and experienced the 'post-conflict' city as shared or divided (Leonard, 2017) ${ }^{(1)}$. These teenagers resided in economically deprived, 
interface areas (areas where Catholics and Protestants live side-by-side apart) and attended separate schools based on Catholic or Protestant affiliation. The research examined how the divided nature of their localities and schools impacted on their micro-geographies. The research took place in schools and involved teenagers outlining their daily spatial movements and reflecting on whether ethno-national identity impacted on the places they visited and felt safe. Of course, at one level, schools are artificial environments as discussing daily spatial practices took place while teenagers were fixed in space and due to constraints on access, it was not possible to include ways of taking teenagers out of school in the research design.

A recent innovation in childhood research is to utilise advisory groups of young people to inform the research. This reflects the increasing emphasis placed on participatory approaches in research and consultation with young people whereby locating them as coparticipants gives recognition to their voice and the varying ways in which it is expressed (Christensen, 2004). This approach was adopted by contacting a youth group to give advice on the various methods utilised in the research. The group were part of the Belfast Youth Forum, a body set up by Belfast City Council to give advice on issues of concern to young people in Belfast. The Forum recruits 40 young people, aged 13-18, who serve for a period of two years. The group are drawn from communities all over Belfast and active policies ensure an even gender, class, religion and ethnic representation based on the overall population profile of Belfast. The existence of the group and their composition as drawn from across Belfast provided a rationale for establishing contact and assessing their willingness to become involved. Contact was made via the youth leader who arranged a meeting. During this meeting, the project was outlined and young people were asked if they would be willing to help with the design of the various methodologies associated with the research. Fifteen young people attended this meeting and 8 expressed willingness to become involved in the research in an advisory capacity. 
However, as the research progressed, the Advisory Group became keenly interested in taking part in the research. They displayed a sophisticated awareness of the limits of schools as a research location and felt that their involvement as mobile participants would significantly add to understanding teenage spatial practices. Hence, they took photos of what Belfast meant to them and these were subsequently discussed. They engaged in 'walk and talk' interviews by bringing me around the city centre pointing out places they liked and disliked and raising awareness of Belfast as a city where, at times, they felt unwelcome due to adult prejudices around teenagers being seen as out of place in adult centred commercial spaces. They discussed their awareness of Belfast as a burgeoning tourist destination and the importance of tourism in displaying the city, at its best and at its worst, as many tours involve dark tourism bringing tourists to places marked by plaques to commemorate atrocities that took place at the height of the troubles.

The importance of Belfast as a 'post conflict' tourist destination came up repeatedly during focus group interviews with teenagers in the wider research where they expressed pride in the visual emblems of their materially deprived localities displaying loyalist and republican identities. In this vein, the Advisory Group suggested that it would be beneficial to the research if they could construct a tour of Belfast and take charge of what they would decide to show tourists visiting Belfast although they would do this within the wider remit of assessing the extent to which the city could be seen as divided or shared. The youth leader keenly supported this suggestion as there was a surplus to the spending budget seeing this potential outing as a social event having an educational benefit rather than a research methodology. Kim (2017) suggests that often blurred boundaries exist between research promoted for educational benefits rather than for supporting the participation of young people in knowledge production. While acknowledging the ambiguities and tensions surrounding the facilitation of young people in research design, it was felt that responding positively to the young people's suggestion would 
enable them to take ownership of parts of the research. The methodology positioned young people as co-researchers but also as research subjects as their goal was to enable me to better understand their attitudes to Belfast by them deciding the method whereby their knowledge production would come to the fore. Hence, the young people positioned themselves as both authors and subjects of knowledge. By enabling me to understand how they viewed the city, they felt this would lead me to ask better questions that would illuminate more effectively the opinions of the participants taking part in the school based research. Responding positively to their request fostered more active engagement by giving them a sense of empowerment over the locations where research interactions would take place bringing to the fore new ways of exploring their socio-spatial relationships.

Nonetheless, the method was not devoid of adult input suggesting an ongoing tension between embracing young people as co-researchers and putting their involvement into practice (Faulkner, 2009). I was deliberately not present when the tour route was discussed by the young people, as I did not want my presence to influence debates around the chosen itinerary but the youth leader was present and facilitated the discussion. She informed me later that the route had involved heated discussions and various compromises over the chosen route. However, I am unable to ascertain the extent to which she influenced the discussion and the compromises reached. For manageability, it was decided to utilise a tour company and guide but that the guide would follow the route decided upon by the Advisory Group. This was sent to the tour company, two weeks before the actual tour took place. It is also worth mentioning that the tours provided by the company are designed with adults in mind. The tour guide was to provide a general commentary on the sites visited but to provide space for young people's narratives to come to the fore. Seventeen young people participated in the tour. This included the 8 members of the Advisory Group and 9 additional members of the Youth Forum. I accompanied the young people on the tour and chatted to them about their choices and observed 
their interaction with the guide. After the tour was completed, I sent a questionnaire to the 17 young people asking them to further discuss and explain the route of the tour. The findings reported below draw on these various components of the methodology.

\section{Teens Co-Constructing Tourism in Belfast}

The time allocated for the tour was two hours and as mentioned earlier, the tour company and guide were presented with the itinerary two weeks before the tour commenced. However, the power imbalance between the tour guide and young people became apparent from the beginning of the tour in that the guide, while visibly holding the schedule produced by young people, indicated that because of time factors, some specified locations would not be visited. The young people constructed the tour around the broad theme of representing a divided or shared city and while the tour moved from one representation to the other, the collective sites representing a shared city narrative will be presented and this will be followed by sites identified by the young people as demonstrating a divided city. The discussion will then move to their identification of other teen specific places, some of which were removed from the itinerary even though their inclusion was linked to illustrating Belfast as divided or shared.

\section{Shared space}

Tourism has become a major industry in Belfast and a proliferation of tour options have become available. Most blend divided Belfast with shared Belfast in that while sites of former conflict are visited, the ethos of most tours is to showcase Belfast as a cosmopolitan city full of cafes, bars, restaurants and exclusive shopping centres such as Victoria Square which is a modern shopping mall located in the centre of Belfast. Teenagers supported the location of the city centre as a shared space and placed a number of city centre sites on their tour route to showcase the city at its best. In addition to Victoria Square, a number of other locations were identified such as Custom House Square (a space in the city centre widely used by teenagers including 
skateboarders), the Odyssey (an entertainment complex) and the Titanic Quarter (a major tourist space celebrating the building of the Titanic in Belfast). In all these locations, teens exhibited pride in their city and felt that any tour of the city should include these venues as examples of shared space. These sentiments are expressed in the following quotes:

Gigs are held here and everyone goes to see them regardless of who they are and what religion they are (reference to Custom House Square).

It is used by skateboarders and for concerts such as Belzoni so anyone can go (reference to Customs House Square).

The Odyssey is a huge multiplex full of facilities for communities to get together and become more friendly (reference to Odyssey Complex).

Concerts and ice hockey matches all happen here and anyone can go (reference to the Odyssey Complex).

I believe it represents the time of the Titanic as there were no troubles back then and hopefully there won't be any in the future (reference to Titanic Quarter)

It shows Belfast and Northern Ireland is going in a new direction away from the troubles and paramilitary activities (reference to Titanic Quarter).

After visiting a number of city centre sites, the tour guide indicated that new, cosmopolitan Belfast was down to them as young people moving Belfast forward.

All these changes are due to you. You represent the future of Northern Ireland. You are the new generation growing up in a new era.

From previous tours offered by this company undertaken by the author, this discourse was not articulated but was introduced specifically on this tour to appeal to the teen audience. Of course, tour guides commonly perform to perceived audiences and in this example, the tour guide replicated the common tendency to see young people in terms of representing the future even though other research suggests that young people in Northern Ireland see themselves as onlookers rather than participants in peace and conflict resolution processes (McCabe and Bourke, 2002). However, the example illustrates that the spatial stories constructed by tour guides are constantly under production and therefore have the potential to incorporate more 
active accounts of young people's situated accounts in their construction, although as this example illustrates, the tour guide's location of teenagers as the future rather than the present needs addressed.

\section{Divided Space}

Professional training often involves tour guides being encouraged to avoid sensitive topics such as politics (Pond, 1993). Rather they are trained and directed to present political commentaries that promote positive images of sites visited and local politics (Dahls, 2002). Of course, dark tourism sites often commodify sites of former conflict. Belfast's most popular tours involve visiting the political wall murals that adorn the walls of republican and loyalist communities and the various 'peace lines' that separate communities. However, here the discourse presented is that one is looking at a past history, as Belfast has left its conflict behind, a position disputed by a number of academic commentators. For example, Hocking (2016: 368) argues that the official discourse in Belfast exhibits a 'veneer of consensus' which steers away from acknowledging ongoing political tensions in the city. Young people with their local knowledge not only questioned this interpretation during the tour but wanted the bus to visit sites where ongoing uneasy relationships between the two communities persisted. In this way, there were demonstrating what McConnell (2001) refers to as a 'second gaze' in that they were aware that tours can deceive by leaving some discourses unsaid.

Teenagers placed two sites on the itinerary that were locations of ongoing sporadic rioting, often involving young people. One was a bridge separating a Catholic from a Protestant community with the location being a site where tensions during the traditional Protestant parading season often result in rioting between Protestant marchers and Catholic residents. As one teenager commented:

It is celebrating a separate religion and a separate culture but in a shared spot. 
The other was a waste ground separating Catholic and Protestant working class communities where teenagers from both communities sometimes congregate and engage in what is referred to locally as 'recreational rioting' (see Leonard, 2010 for a critique of this concept). Since the research was carried out, an art installation has been installed on this waste ground and this has led to reduced tensions in the area. This example illustrates how places are never fixed or static. They are constantly enacted through the actions of planners, policymakers, residents and users of space. Revisiting this site would probably result in new discourses being produced (and indeed contested) demonstrating that what places show or mean is always ambiguous and dynamic. The company's website and pamphlets advertising tours and itineraries do not include either of these two locations. As mentioned previously, this is due to the common tendency to portray Belfast as a 'post conflict' city rather than a city struggling to maintain its 'post conflict' status. For some of the young people, their everyday realities called into question this partial discourse and they were keen to emphasise that presenting Belfast should not shy away from showing the city 'warts and all'. They felt that visiting such sites would encourage more dialogue on confronting the need to address ongoing tensions and identify relevant policies to tackle segregation. Visiting these sites encouraged reflection on ongoing divisions and how they might be overcome. Young people discussed the need to tackle residential segregation by supporting more shared housing projects and organising more cross community events. These examples illustrate the teenagers' perception that difference needs to be confronted and challenged rather than ignored. Their everyday experiences positioned them as political actors able to confront the political realities that reflect their everyday lives where their political identities are experienced and performed. Young people discussed how they hoped for a future Belfast where difference and diversity could be celebrated rather than treated with intolerance or ignored. But they lamented the lack of opportunities for multiple 
perspectives on the sharing of space and how young people's everyday experiences in public space are often marginalised or neglected.

\section{Unvisited Sites}

As outlined earlier, some sites placed on the itinerary were left out of the tour and the tour guide claimed that this was because of limits on time. In this way, there was some attempt on the part of the guide to construct and regulate the teenagers' gaze. For example, the first place young people wanted to visit was the zoo which is located approximately five miles from the city centre of Belfast. The guide indicated that if the zoo was visited. then other sites identified by them would have to be excluded and this was met with a chorus of disapproval from the teenagers. While the tour guide appeared to be offering a compromise, this was not discussed with teenagers and was presented as a decision made by the tour guide. Since the guide had access to the itinerary two weeks before the tour commenced, this could have been pointed out and put back to teenagers to redesign the itinerary. The tour guide further justified the exclusion by indicating that it would add nothing to the overall theme of the tour. It was not a site placed on the 'normal' itinerary and while she acknowledged it was likely to be a shared space, there were other more interesting and relevant examples to visit.

The zoo was seen by teenagers as a shared space that everyone could enjoy. Many young people discussed happy memories of visiting the zoo with their families when they were younger. But young people wanted to move beyond these limited discourses and hoped to utilise the site to illustrate how the common markers of identity and difference prevalent in Belfast would be irrelevant in the animal kingdom. Some young people discussed how people could learn from animals as they would not differentiate on the basis of Protestant or Catholic identity. In their view, this justified its inclusion as the first port of call on tours of 'post 
conflict' Belfast as it would send a stark message to tourists that perceived differences between human beings could be attributed to prejudice. The following quotes reflect these views:

The Belfast zoo is equal and accessible to any religion or ethnicity and the animals don't care who visits them

Belfast zoo is a good example of a shared space as it is a tourist attraction and brings in people from all difference religions, races etc.

Belfast zoo is an example of a shared space because it brings in lots of people no matter what religion or race they are and the animals don't treat people differently

Everyone can go no matter of their age, gender or sexuality and it enables everyone to feel welcome.

Moreover, the teenagers wanted to visit what they referred to as the 'largest Kentucky Fried Chicken' restaurant in Ireland. This was located within close proximity to other sites visited but was left out because once again the guide felt it would not add much to the overall theme of the tour. Yet, young people justified the inclusion in terms of representing Belfast as a shared city. The eating venue was frequented by teenagers and was regarded as one where mutual indifference and tolerance of the other community was the norm. To add further justification, some teenagers talked about how the place was visited by long-distance lorry drivers who in their view were unconcerned with local politics, as many would come from outside Northern Ireland. These examples illustrate how young people may possess different 'ways of seeing' from the adult population. The two sites discussed here were trivialised by the tour guide as specific teen places or family spaces with little relevance for the overall theme of the tour on identifying markers of sameness and difference. Yet, young people injected personal meanings into these places and infused both locations with having the potential to demonstrate shared space illustrating how the same place can be portrayed in a multiplicity of ways.

\section{Challenging the Tour Guide}


Gazing reflects complex social relations between adults and children, tour guides and tourists and within the tourist population that simultaneously gaze at the same place. The power relationships underpinning these forms of gazing are fluid and dynamic. Tour guiding is often seen as a one-way process whereby the guide points out what to see and how to interpret what is seen (Uri, 2002) and indeed, the hierarchal power relationship between the guide and the teens was apparent at the outset in that the first site specified by young people was not included in the tour. However, gazing is an interactional process. Larsen and Westfeldt (2013) liken the role of the tour guide to that of teacher. They have temporary authority over tourists and expect them to pay attention. At the beginning of the tour, the guide adopted a pseudo-teacher role and assumed this would be achievable through her adult status. Teenagers were expected to remain in the same seats for the duration of the tour and listen and not interrupt the discourse on offer unless invited to do so. Initially teenagers' talking to each other was greeted with looks of disapproval and they were asked (albeit politely) to refrain from engaging in conversations while she was speaking. However, throughout the tour, young people moved around the bus to engage in conversation with other teenagers and at times during instances when the tour guide was speaking. Hence young people's listening behaviour moved from active attention to partial attention to inattention. In these ways, the power of the adult tour guide to control the tour and the teenage audience was diluted.

Larsen and Westfeldt (2013) outline the fluid power relationship between adult tourists and adult guides in order to demonstrate how adult tourists often bring their own agendas to the guided tour and use this to interfere with and resist the narrative on offer. Mao (2006) utilises the concept of the 'mutual gaze' to illustrate how locals in particular often draw on their host knowledge to challenge and resist the official tourist gaze although again the assumption is that this process takes place between adult tour guides and adult locals, rather than between adult tour guides and young people, as members of host communities. Yet, throughout the 
tour, this 'mutual gaze' was embraced by teenagers through the various instances where the discourses produced by young people contradicted the tour guide's script. During the tour, young people positioned their knowledge against that of the tour guide and at various points, the tour guide had to bend the script in response to young people's narratives. For example, as outlined above, young people placed on the agenda, the visiting of contentious sites where tensions between Catholics and Protestants are ongoing. While at these sites, young people referred to and resisted the tour guide's unproblematic 'post conflict' narrative that had preceded visiting these locations. In this way, the tour was performed and co-created by young people and their multiple narratives demonstrated the dynamic nature of the encounter. While this approach has been applied to adults on tours, to date, the agency of young people and their impact on tour guides has been largely absent (Jonas son and Scheele, 2012).

\section{Disagreement within group}

In the discussion presented thus far I do not want to imply that there is one teenage gaze. Throughout the tour, it was apparent that teenagers subjected the landscape to varied often contested gazes. Hence, while the teenagers in this study did not simply represent a tourist audience but actively challenged the guide's discourse, nonetheless, their performance also had to take on board the gaze of co-participants. The planned route was co-constructed with other members of the peer group and the final itinerary reflected not just individual gazes but the gazes of others. The subsequent sites visited, particularly relating to shared space, were often enabled and constrained by the presence and gaze of the other teens on the bus and by the choices made by the tour guide. This suggests that how these teenagers produced and defined their social identities was far from straightforward. This was clearly brought to the fore through the inclusion of various sporting venues as examples of shared space. 
Four young people suggested the inclusion of four venues, two typically associated with Protestant sport and two typically associated with Catholic sport. This suggests that a form of negotiation had taken place in planning the route with teenagers opting for equal inclusion across the traditional sectarian divide. Since I was not present at the planning stage of the route, I am unable to determine how these decisions and compromises were reached. For time purposes, the guide, once again, diverged from the teenagers' pre-planned route and selected two of the identified sites, both reflecting sports more typically supported by Protestant communities, simply because they were located close to other sites to be visited during the tour. At times, sporting events cultivate sectarian rivalry and act as a catalyst for sectarian clashes with the location of the largely Protestant and Catholic stadiums placed in areas which reflect the largely segregated sectarian geography of the city. The guide stated that none of the four sporting sites were included in their tours of the city and assumed that their inclusion was to represent contested space. This was challenged by the proposers who indicated that by contrast, their intention was to illustrate shared space. Sport was seen as having the potential to reduce sectarian divisions and encourage cross-community relations

The proposers of each space were invited to the front of the bus to speak through the tour guide's microphone to the bus occupants on why they had proposed the sites. While two sites were being excluded, as a compromise, the proposers of the two unvisited sites were also invited to the microphone to justify and defend choices. During these periods, disagreement between the teenagers on what was shared space and what was divided was clearly evident, again demonstrating that there is no one teenage gaze. In relation to (largely Protestant) Windsor Park, John ${ }^{(2)}$, the proposer of the venue told the group that

Windsor is a great place to go. Everyone can enjoy visiting here. We have the best football club in the world. Alan (no surname given) is one of the most sought players around and he's ours. 
This was met by disagreement from the Catholic teenagers on the bus, some of whom indicated that while they loved football, they had never been to a match at Windsor Park because of fears for safety. The incident led to heated debates around what could be considered as shared or divided space and it was clear that Protestant/Catholic identity markers played a role in how space was interpreted. Interestingly, teenagers who viewed sport taking place in their own localities as shared did not extend this interpretation to sports that took place in what they defined as the 'other community'. For example, when Cahill, the proposer of (largely Catholic) Casement Park claimed that this space could be seen as shared, John responded:

It's in a nationalist area and the ground is named after a terrorist.

While Casement Park was not visited on the tour, it was clear that some of the Protestant teenagers on the bus had never been to the area where the Park was located because of perceptions that the general area was in the words of Raymond too nationalist and too Catholic'.

This suggests ongoing messy relationships to space and place with teenagers constructing a route where some venues were left unvisited by the tour guide but where in turn, some of the teenagers had never visited. At the same time, some teenagers appeared open to the identification of some sites as 'shared' by their peers and acknowledged that their views were based on perceptions amassed from their community backgrounds rather than direct experiences. Visiting these unvisited spaces in the company of peers who were making a claim for seeing a venue as shared encouraged some teenagers to revisit their own preconceptions and begin to unpack one-sided narratives by acknowledging that perceptions of place are likely to provoke counter-narratives. 
While this example relates to sporting venues, it suggests that the choices relating to the other sites mentioned throughout this article were likely influenced by similar processes of negotiation which resulted in some sites being visited while others were excluded and with each site being the end product of debates between young people which may not necessarily have been harmonious. The presence of varied gazes at these venues turned what one considered as shared space into contested space as defined by others. At various times, the discourse presented by one teenager was resisted by other teenagers. As such, there was no such thing as a collective teenage gaze. Being in place and talking about place enabled competing narratives to come to the fore reminding us that while place is likely to play a core role in identity formation, the knowledge on which it is based, is likely to be partial and situated.

\section{Conclusion}

This article had two main aims. Firstly, to address the relative neglect of young people's perspectives in tourism research and secondly, to illustrate how they could contribute to tourism theory and practice by outlining a case study from Belfast where young people took partial ownership of a city tour. The case study involved a methodology where teenagers in Belfast constructed a tour route for a tour guide to follow. In this way, teenagers influenced and disrupted the usual relationship between tour guide and tourists. While interpretation is often conceptualised as the tour guide's responsibility, in this case, young people played a significant part in interpreting the places visited. The bus tour brought their situated knowledge to the fore. Throughout the tour, the teenagers disputed the expert opinion of the tour guide and provided a commentary that often called into question, the account provided by the tour guide and challenged the knowledge source on which it was based. Hence, they moved beyond their general location as powerless consumers of adult-defined tours to inscribe places with their own stories and from time to time exercised power by challenging and recreating the discourse on offer. If we view power as the situated outcome of performances, the example 
demonstrates the fallacy of viewing power between adults and children as fixed and unchanging. Leonard (2017) argues that where young people provide 'situated' practical knowledge about a research topic, the benefits should not be underestimated. Clearly the young people had local knowledge and drew on local experiences and were able to demonstrate, throughout the tour, their social connectedness to place. Their individual teenage gaze was responsive to the gaze of other teenagers so that discourses of difference were accommodated rather than avoided. Tourism studies could benefit from greater exploration into how places are lived and experienced by younger people, particularly in divided cities.

Throughout the tour, young people demonstrated their capacity to actively contribute to the design of the tour. Being able to direct the route of the tour, although not always successfully, enabled them to partly shape the focus of the research. Their ability to communicate their own experiences brought added value to their perceptions and experiences of touring Belfast and impacted on the tour guide's evaluation of the city. Giving young people a sense of ownership over places visited allows for the co-creation of tours and this example could be embraced positively by tour organisations who could develop a teen market whereby tour guides could provide the space and opportunity to enable young people's local experiences and knowledge to feed into and bring added value to the product on offer. While a number of studies have outlined the capacity for adults to contribute to the co-creation of tours (Wailer and Black, 2015), the competency of children and young people to play a similar role has been largely ignored and unexplored.

But more importantly, the research gave young people the scope to reimagine and recreate their own sense of place. The teenagers co-wrote the script and in the process produced their own version of the guided tour. In this way, the teenagers were able to give meaning to their micro-geographies and how this impacts on their individual and collective identities. The places visited indicated their willingness to acknowledge ongoing places of contention and 
their inclusion of sporting venues and the competing discourses produced in relation to perceptions of such spaces highlights the importance of developing space in ways that could improve inter-communal relations. One of the core findings of the wider research was the ignorance of teenagers living in segregated areas regarding adjacent residential spaces occupied by the other community (Leonard, 2017). The majority of teenagers in the wider research suggested that they had never ventured into adjoining communities because of their preconceived fears that often centred on demonising the other. Resourcing teenagers to provide tours of their own communities and enabling them to bring other teenagers to places they claim are 'shared' would enable traditional discourses around division to be confronted and challenged along with the ignorance of space on which they are based. While there is no claim here that local teenagers bring an authentic gaze to tours, they do bring ways of seeing that could pave the way for more effective engagement with other groups of local teenagers in future tours by facilitating the need to develop mutual understanding of what constitutes shared and divided space.

Notes:

(1). The research on teenagers growing up in post-conflict Belfast was supported by an ESRC Grant - Grant Number RES-060-25-0015

(2). Pseudonyms are used throughout this paper.

\section{References:}

Celle, S. (2013) 'Performing the Political through Public Space: Teenager Girls' Everyday Use of a City Park', Space and Polity, 17, 1, 74-87.

Christensen, P. (2004) 'Children's Participation in Ethnographic Research: Issues of Power and Representation' Children and Society, 18, 2, 165-76.

Dahls, H. (2002) The Politics of Tour Guiding: Image Management in Indonesia, Annals of Tourism Research, 29, 783-800.

Faulkner, K. (2009) 'Representation and Representation: Youth Participating in On-going Public Decision-making Projects', Childhood, 16,1, 89-104. 
Hargie, O. and Dickson, D. (2003) Researching the Troubles: Social Science Perspectives on the Northern Ireland Conflict, London: Mainstream Publishing.

Hocking, B. (2016) 'Gazed and Subdued? Spectacle, Spatial Order and Identity in the Contested City', Tourist Studies, 16, 4, 367-85.

Jonasson, M. and Scherle, N. (2012) Performing Co-Produced Guided Tours, Scandinavian Journal of Hospitality and Tourism, 12, 55-73.

Kerr, M. and Price, R. (2018) "I know the Plane Crashed": Children's Perspectives on Dark Tourism', in Stone, P., Hartmann, R., Seaton, T. Sharpley, R. and White, L. (eds.) The Palgrave Handbook of Dark Tourism Studies, London: Palgrave/macmillan.

Kerr, M. and Price, R. (2016) 'Overlooked Encounters: Young Tourists' Experiences at Dark Sites’, Journal of Heritage Tourism, 11, 2, 177-85.

Kim, C. (2017) 'Participation or Pedagogy? Ambiguities and Tensions surrounding the Facilitation of Children as Researchers', Childhood, 24, 1, 84-98.

Larsen, J. and Widtfeldt Meged, J. (2013) Tourists Co-Producing Guided Tours, Scandinavian Journal of Hospitality and Tourism, 13, 2, 88-102.

Leonard, M. (2017), Teens and Territory in 'Post-Conflict' Belfast: If Walls Could Talk, Manchester, Manchester University Press.

Leonard, M. (2010) 'What's Recreational about Recreational Rioting', Children and Society, $24,1,38-50$

MacCannell, D. (2001) ‘Tourist Agency', Tourist Studies, 1, 1, 23-37.

Maoz, D. (2006) 'The Mutual Gaze', Annals of Tourism Research, 33, 221-39.

McAlister, S., Scraton, P. and Haydon, D. (2014) 'Childhood in Transition: Growing up in "Post Conflict” Northern Ireland', Children's Geographies, 12, 3, 69-83.

McCabe, D. and Bourke, T. (2002) Interim Report for the Northern Ireland Fund for Reconciliation, Dublin: The Training Trust.

Nolan, P. (2014) Northern Ireland Peace Monitoring Report No.3, Belfast: Community Relations Council.

Pond, C. (1993) The Professional Guide: Dynamics of Tour Guiding, Hoboken: John Wiley.

Poria, Y. and Timothy, D. (2014) 'Where are the Children in Tourism Research', Annals of Tourism Research, 47, 77-95.

Price, R. and Kerr, M. (2018) 'Children's Play at War Memorials: Insights from a Social Media Debate', Journal of Heritage Tourism, 13, 2, 167-80.

Sibley, D. (1995) Geographies of Exclusion, London: Routledge.

Skelton, T. and Gough, K. (2013) 'Introduction: Young People's Im/Mobile Urban Geographies, Urban Studies, 50, 3, 455-66. 
Smith, D. and Mill, S. (2019) 'The "youthfulness" of Youth Geographies: "coming of age"?, Children's Geographies, 17, 1, 1-8.

Urry, J. (2002) The Tourist Gaze: Leisure and Travel in Contemporary Societies, London: Sage.

Weiler, B. and Black, R. (2015) 'The Changing Face of the Tour Guide: One-Way Communicator to Choreographer to Co-Creator of the Tourist Experience', Tourism Recreation Research, 40, 3, 364-78. 